\title{
Spatial Distribution, Pollution Characteristics and Source of Heavy Metals in Farmland Soils around Antimony Mine Area, Hunan Province
}

\author{
Yanli Jia ${ }^{1,2}$, Wei Zhang ${ }^{2}$, Min Liu ${ }^{2}$, Yingao Peng ${ }^{3}$, Chunming Hao ${ }^{2 *}$ \\ ${ }^{1}$ China University of Mining and Technology (Beijing), Beijing, 100083 \\ ${ }^{2}$ North China Institute of Science and Technology, Sanhe, Hebei Province, 065201 \\ ${ }^{3}$ Institute of Disaster Prevention Science and Technology, Sanhe, Hebei Province, 065201
}

Received: 19 May 2021

Accepted: 18 September 2021

\begin{abstract}
The heavy metal pollution of soil caused by mining activities has attracted widespread attention. This study investigates the spatial distributions, pollution characteristics, and sources of nine heavy metals ( $\mathrm{Ni}, \mathrm{Cu}, \mathrm{Pb}, \mathrm{Zn}, \mathrm{Cr}, \mathrm{Cd}, \mathrm{As}, \mathrm{Sb}$, and $\mathrm{Hg}$ ) in the farmland soil around an antimony mine, Hunan Province, China. The results show that the average contents of $\mathrm{Ni}, \mathrm{Cu}, \mathrm{Pb}, \mathrm{Zn}, \mathrm{Cr}, \mathrm{Cd}, \mathrm{As}, \mathrm{Sb}$, and $\mathrm{Hg}$ are all above the background values of the surface soil in Hunan Province, and the mean concentrations of $\mathrm{Cd}$ and As have exceeded China's soil pollution risk screening values for agricultural land. The highest $\mathrm{Sb}$ content obtained in this study is 1234.3 times of the maximum allowable antimony content in the soil. The average content of heavy metal elements in the farmland soil samples shows the following trend: $\mathrm{Sb}>\mathrm{Zn}>\mathrm{Cr}>\mathrm{As}>\mathrm{Pb}>\mathrm{Ni}>\mathrm{Cu}>\mathrm{Cd}>\mathrm{Hg}$. The content of each heavy metal in garden land is higher than that in arable land. Geoaccumulation index analysis results suggest the overall pollution level of the farmland soil is light. In some areas, the pollution level of $\mathrm{Cd}$ has reached moderate to strong pollution, the pollution levels of $\mathrm{Sb}$ and $\mathrm{Zn}$ appear to be moderate pollution to moderate to severe pollution, and the pollution levels of $\mathrm{Ni}, \mathrm{Cu}, \mathrm{Pb}, \mathrm{Cr}, \mathrm{As}$, and $\mathrm{Hg}$ are at moderate pollution to light pollution. The correlation analysis and positive matrix factorization (PMF) analysis reveal that As, $\mathrm{Sb}$, and $\mathrm{Hg}$ are mainly caused by the mining activity, the agricultural activity is the main reason for the accumulation of $\mathrm{Cd}$, and natural factors are the main sources of $\mathrm{Cu}, \mathrm{Pb}, \mathrm{Cr}, \mathrm{Ni}$, and $\mathrm{Zn}$ in the study area.
\end{abstract}

Keywords: heavy metals, spatial distribution, pollution characteristics, source identification

\section{Introduction}

Heavy metal refers to any metal element with a density above $4.5 \mathrm{~g} / \mathrm{cm}^{3}$, such as cadmium (Cd), mercury $(\mathrm{Hg})$, lead $(\mathrm{Pb})$, copper $(\mathrm{Cu})$, zinc $(\mathrm{Zn})$, chrome $(\mathrm{Cr})$, nickel (Ni), antimony (Sb), and arsenic (As) [1-2]. Elevated heavy metal content in soil has a huge impact on the growth of plants, including changes in the appearance of the plants (such as color, leaf shape, and size) and even death [3]. Heavy metal pollution in soil has become a worldwide environmental problem, 
and the major pollution source is human activity, including mining, smelting, fossil-fuel combustion, and sewage sludge incineration [4-5].

Soil scientists have carried out extensive research on the spatial distribution, pollution level, and pollution sources of soil heavy metals. Rodríguez and coworkers found that the mean concentrations of $\mathrm{Pb}, \mathrm{Zn}, \mathrm{Cd}$, and $\mathrm{Cu}$ in the soil samples collected at an old Spanish $\mathrm{Pb}-\mathrm{Zn}$ mine were $28453.50 \mathrm{mg} / \mathrm{kg}, 7000.44 \mathrm{mg} / \mathrm{kg}$, $20.57 \mathrm{mg} / \mathrm{kg}$, and $308.48 \mathrm{mg} / \mathrm{kg}$, respectively. Besides, a high level of $\mathrm{Pb}, \mathrm{Zn}$, and $\mathrm{Cd}$ pollution was also found in the samples taken from surrounding arable and pasture lands, indicating a certain extent of spreading of heavy metal pollution, which was mainly caused by acidic drainage and dust transport [6]. The study carried out by Akanchise and coworkers showed that the contents of heavy metals in the soil samples collected from abandoned dump sites in Kumasi, Ghana had the following order: $\mathrm{Zn}(166 \mathrm{mg} / \mathrm{kg})>\mathrm{Cr}(67 \mathrm{mg} / \mathrm{kg})$ $>\mathrm{Cu} \quad(32 \mathrm{mg} / \mathrm{kg})>\mathrm{Ni} \quad(22 \mathrm{mg} / \mathrm{kg})>\mathrm{Pb} \quad(11 \mathrm{mg} / \mathrm{kg})>\mathrm{Cd}$ $(8.9 \mathrm{mg} / \mathrm{kg})>\mathrm{As} \quad(4.2 \mathrm{mg} / \mathrm{kg})>\mathrm{Hg} \quad(0.04 \mathrm{mg} / \mathrm{kg}) \quad[7]$. Wang and coworkers revealed that the soil of Dexing Copper Mine in Jiangxi, China, was heavily polluted. The average $\mathrm{Cu}$ content in the soil was 10 times of the normal value. The $\mathrm{Cu}$ pollution was mainly caused by wastewater, dust, and tailing piles of the local copper mines through sedimentation, rain, and water washing [8]. Wen and coworkers found that the $\mathrm{Pb}$ and $\mathrm{Cd}$ pollution in the topsoil around the Jinding $\mathrm{Pb}-\mathrm{Zn}$ mine in China was caused by surface mines and zinc smelters [9]. In summary, industrial and mining activities are the main sources of soil heavy metal pollution in mining areas.

The Xikuangshan mine in Hunan Province has China's largest antimony deposit, and the soil in this mining area has been seriously polluted by hundreds of years of mining activities. Mo and coworkers found that the concentrations of $\mathrm{Sb}, \mathrm{As}$, and $\mathrm{Hg}$ in the soil near the mining area, smelting area, and tailing area of the antimony mine were $141.92 \sim 8733.26 \mathrm{mg} / \mathrm{kg}$, $14.95 \sim 363.19 \mathrm{mg} / \mathrm{kg}$, and $0.16 \sim 5.68 \mathrm{mg} / \mathrm{kg}$, respectively, which largely exceeded the soil background value of Hunan Province [10]. He and Wan reported that the soil in the mining area was heavily polluted by $\mathrm{Sb}$ and As, and the contents of heavy metals including $\mathrm{Hg}, \mathrm{Cr}, \mathrm{Zn}, \mathrm{Cd}, \mathrm{Pb}$, and $\mathrm{Cu}$ were also high [11]. In addition, the plants in the mining area also showed high antimony pollution. For example, the content of antimony in radish root samples and radish leave samples was $3.0 \sim 10.5 \mathrm{mg} / \mathrm{kgand} 1.5 \sim 121.4 \mathrm{mg} / \mathrm{kg}$, respectively [12]. However, the aforementioned researches are mainly focused on the mining area, and there are few studies on the influence of mining activities on the farmland soil around the mining area. The long history of Sb-related mining and smelting activities caused high concentrations of heavy metals in the soils around the mine area.Therefore, the analysis of pollution status and source of heavy metals in soils around mine area is very important.
In this study, an antimony mine located at Lengshuijiang, Hunan, China is chosen to study the spatial distributions, pollution characteristics, and sources of heavy metal pollutants. The main goals of this study are: (1) to investigate the concentrations of $\mathrm{Ni}, \mathrm{Cu}, \mathrm{Pb}, \mathrm{Zn}, \mathrm{Cr}, \mathrm{Cd}, \mathrm{As}, \mathrm{Sb}$, and $\mathrm{Hg}$ in the farmland soil around the antimony mine; (2) to evaluate the pollution status using geoaccumulation index; (3) to identify possible sources of heavy metal pollutants using a positive matrix factorization (PMF) model.

\section{Materials and Methods}

\section{Brief Description of the Study Area}

Xikuangshan is located in central Hunan province of China, is well known as the world's largest Sb mine. This mine situates between $27.7^{\circ} \mathrm{N}$ and $111.4^{\circ} \mathrm{E}$ with a total area of approximately $26 \mathrm{~km}^{2}$. As can been seen in Figure 1. It has a subtropical continental monsoon climate, with sufficient sunlight, four distinct seasons, and a mild weather condition. The average annual temperature is $16.5^{\circ} \mathrm{C}$ and the average annual precipitation is $1648 \mathrm{~mm}$. The elevation of the mining area is high in the north and low in the south, which is a typical low mountain and hilly landform [13]. With a total population of over 16 thousand, this area has 15 villages, 14 antimony mining companies, a school, a residential community center, a market, and residential areas.

\section{Sample Collection}

A total of 130 soil samples were collected in July 2020. The sampling locations are shown in Fig. 1. The checkerboard sampling method was employed based on the landform and soil uniformity of the sampling area. Before sampling, weeds and gravel were removed. Then, a $5 \mathrm{~m} \times 5 \mathrm{~m}$ grid pattern was laid out on the field, and the surface soil at $0-20 \mathrm{~cm}$ in depth was collected with a wooden shovel at the 4 corners and the center of the grid. After that, the collected soil was thoroughly mixed, and the amount of the soil sample was reduced with the quartering method until 1-2 kg was left. Finally, the sample was collected in a cloth bag and labeled.

\section{Sample Processing and Analysis}

First, the soil samples were air-dried in an indoor ventilated environment. Then, the samples were sieved through a $2 \mathrm{~mm}$ sieve to remove non-soil materials, i.e. wood chips and grassroots. After that, the sample was ground until passing through a $0.149 \mathrm{~mm}$ nylon sieve, which was stored for further analysis. The soil samples need to be digested with microwave. Digestion solutions used include nitric acid (content, 65 68\%), hydrofluoric acid (content, 40\%), and hydrochloric acid (content, $37 \%)$. 


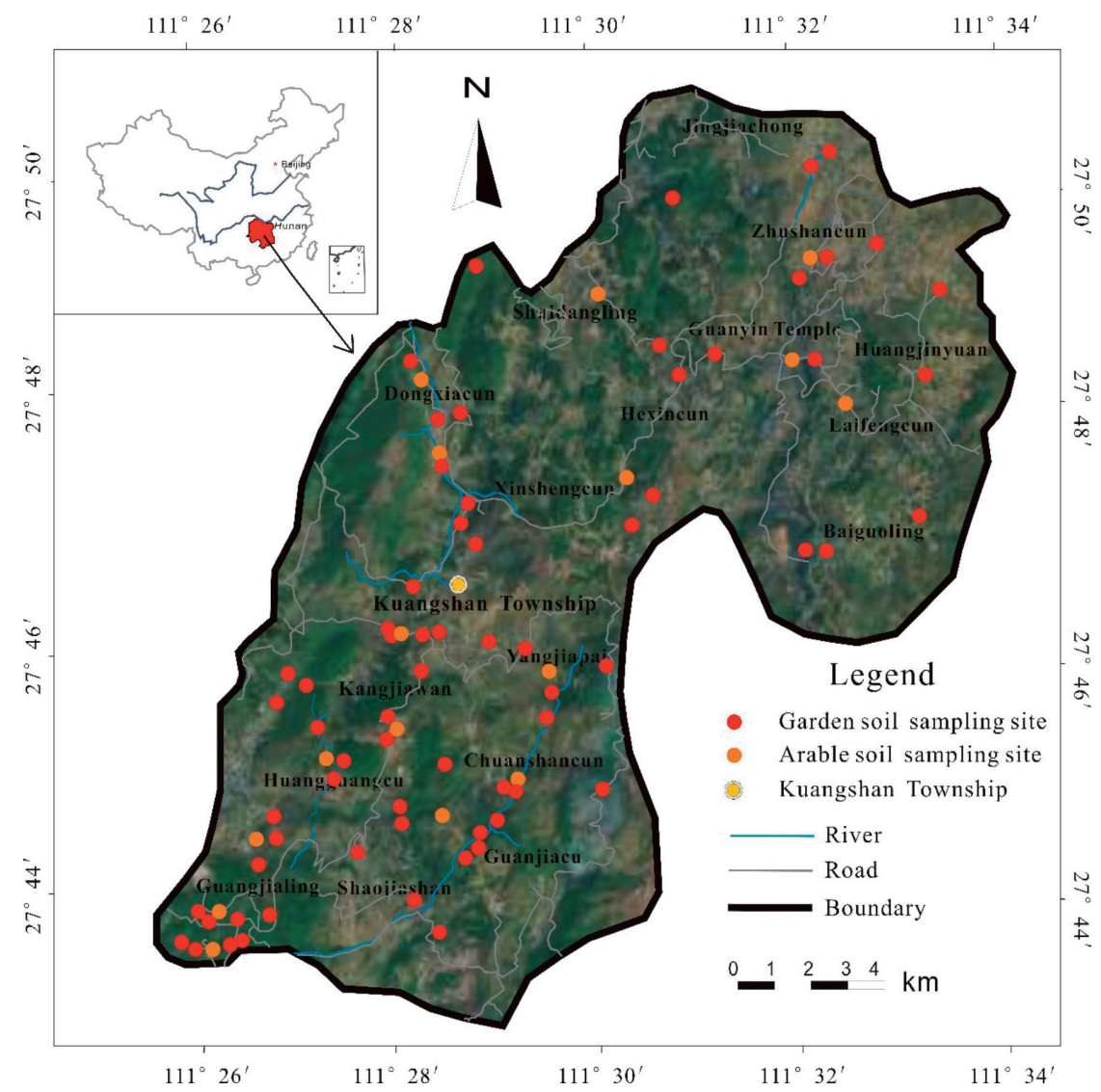

Fig.1. Geographical location and sampling point distribution map of the study.

The contents of $\mathrm{Cu}, \mathrm{Ni}, \mathrm{Cd}, \mathrm{Cr}, \mathrm{Pb}$, and $\mathrm{Zn}$ were determined by an inductively coupled plasma mass spectrometer (ICPMS-7000, Beijing Jitian Instrument Co., Ltd., China), and the contents of As and $\mathrm{Hg}$ were measured using a hydride generation atomic fluorescence spectrometry (AFS-9700, Beijing Haiguang Instrument Co., Ltd., China), and the $\mathrm{Sb}$ content was analyzed by a flame atomic absorption spectrometry(GGX-600AAS, Beijing Kechuang Haiguang Instrument Co., Ltd., China). The quality during digestion and ultimate analysis was controlled by using national standard substances (GBW07406). Each sample was independently measured for 3 times. Blank sample tests were also performed, and the recovery rate of each heavy metal element $(\mathrm{Ni}, \mathrm{Cu}, \mathrm{Pb}, \mathrm{Zn}, \mathrm{Cr}, \mathrm{Cd}$, $\mathrm{As}, \mathrm{Sb}$, and $\mathrm{Hg}$ ) ranges from $90 \%$ to $110 \%$, proving the accuracy of the measurements.

\section{Evaluation Method}

\section{Geochemical Baseline Determination}

There are three principal methods for determining the soil geochemical baseline value: standardized method, statistical method, and geochemical comparison method [14]. In this study, the standardized method is employed. The basic principle of this method is using the concentration of an inert element in the geochemical process as a reference (standard element) to obtain the concentration of active elements through the linear regression equation between them (Eq. (1)) [15].

$$
C_{m}=a C_{n}+b
$$

where $C_{m}$ is the measured concentration of an active element in the sample; $C_{n}$ is the measured concentration of the standard element in the sample; $a$ and $b$ are regression coefficients. Appling Eq. (1) to a statistical test with $95 \%$ confidence intervals, the samples falling within the $95 \%$ confidence intervals represent the range of the baseline. Then, the regression coefficients, $a$ and $b$, can be determined through statistical analysis.

Based on the average content of the standard element in the soil of the study area, the average content of each active element (or the baseline value, $\mathrm{Bm}$ ) can be calculated with Eq. (2).

$$
B_{m}=a C_{N}+b
$$

where $B_{m}$ is the baseline value of active elements, and $C_{N}$ is the average content of the standard element.

The standard elements for geochemical baseline study are selected based on local geological background and human activities. $\mathrm{Al}, \mathrm{Fe}, \mathrm{Ti}, \mathrm{B}, \mathrm{Zr}$, and $\mathrm{V}$ are commonly used as standard elements [16]. Through 
data analysis, it was found that the overall variation coefficient and deviation of $\mathrm{Ti}$ in the study area are the smallest among commonly used standard elements, indicating that the content of $\mathrm{Ti}$ is relatively stable and less affected by human activities. Hence, in this study, Ti is used as the standard element.

\section{Geoaccumulation Index Analysis}

The geoaccumulation index method was proposed by the German scientist, Müller, in the 1960s. It can be not only used to evaluate the distribution of heavy metals in sediments but also assess the impact of human activities on the environment [17]. The heavy metal pollution classification standard [18] is shown in Table 1, and the geological accumulation index (Igeo, a dimensionless unit) is calculated based on Eq. (3):

$$
\text { Igeo }=\log _{2}\left\{\frac{C_{i}}{\mathrm{k} * B_{i}}\right\}
$$

where $C_{i}$ is the concentration of the heavy metal element, $\mathrm{i}$, in the soil; $B_{i}$ is the background value of the heavy metal, i, in the soil of Hunan Province[19], China; $\mathrm{k}$ is the modification index (generally, $\mathrm{k}=1.5$ ).

\section{PMF Source Analysis Method}

PMF is a multivariate factor analysis technique that is commonly used in environmental pollution source analysis [20]. This model uses uncertainty to analyze the quality of each concentration data. If the concentration of a heavy metal element is below the detection limit of the determination method (MDL), the uncertainty, $U_{n c}$, is calculated according to Eq. (4):

$$
U_{n c}=5 / 6^{*} \mathrm{MDL}
$$

If the concentration of a heavy metal element exceeds the MDL value, the following equation is applied.

$$
U_{n c}=\sqrt{\left(\mathrm{EF} * X_{i j}\right)^{2}+(0.5 * \mathrm{MDL})^{2}}
$$

where $\mathrm{EF}$ is the determination precision, which is 0.2 in this study (it generally lies between $0.05-0.3$ ); $X_{i j}$ is the concentration of the jth element in the ith sample.

\section{Statistical Analysis}

All statistical analyses are performed by SPSS 19.0, including descriptive statistical analysis of heavy metal elements and Pearson correlation analysis. The PMF5.0 software is used to analyze the sources of heavy metals in soil. The ArcGIS10.2.2 is used to determine the pollution distribution of heavy metal elements contents in the study area.

\section{Results and Discussion}

\section{Characteristics of Soil Heavy Metal Content}

The statistical characteristics of the contents of $\mathrm{Ni}$, $\mathrm{Cu}, \mathrm{Pb}, \mathrm{Zn}, \mathrm{Cr}, \mathrm{Cd}, \mathrm{As}, \mathrm{Sb}$, and $\mathrm{Hg}$ in the 130 samples were listed in Table 2. It can be seen that the average content of heavy metals show the following trend: $\mathrm{Sb}$ $(413.21 \mathrm{mg} / \mathrm{kg})>\mathrm{Zn} \quad(167.33 \mathrm{mg} / \mathrm{kg})>\mathrm{Cr}(86.23 \mathrm{mg} / \mathrm{kg})$ $>$ As $(52.73 \mathrm{mg} / \mathrm{kg})>\mathrm{Pb}(46.16 \mathrm{mg} / \mathrm{kg})>\mathrm{Ni}(32.31 \mathrm{mg} / \mathrm{kg})$ $>\mathrm{Cu}(32.52 \mathrm{mg} / \mathrm{kg})>\mathrm{Cd}(2.56 \mathrm{mg} / \mathrm{kg})>\mathrm{Hg}(0.88 \mathrm{mg} / \mathrm{kg})$, and the corresponding concentration ranges are $3.74 \sim 4320.00 \mathrm{mg} / \mathrm{kg}, \quad 50.00 \sim 2275.62 \mathrm{mg} / \mathrm{kg}$, $45.00 \sim 156.00 \mathrm{mg} / \mathrm{kg}, 9.57 \sim 552.00 \mathrm{mg} / \mathrm{kg}, 8.20 \sim 193.25$ $\mathrm{mg} / \mathrm{kg}, \quad 15.88 \sim 95.70 \quad \mathrm{mg} / \mathrm{kg}, \quad 13.90 \sim 129.00 \quad \mathrm{mg} / \mathrm{kg}$, $0.15 \sim 42.89 \mathrm{mg} / \mathrm{kg}$, and $0.08 \sim 8.07 \mathrm{mg} / \mathrm{kg}$. The average contents of $\mathrm{Ni}, \mathrm{Cu}, \mathrm{Pb}, \mathrm{Zn}, \mathrm{Cr}, \mathrm{Cd}, \mathrm{As}, \mathrm{Sb}$, and $\mathrm{Hg}$ are all above the soil background values in Hunan Province, while the average concentrations of $\mathrm{Ni}, \mathrm{Cu}$, $\mathrm{Zn}, \mathrm{Cr}, \mathrm{As}, \mathrm{Sb}$, and $\mathrm{Hg}$ still below China's soil pollution risk screening values (GB15618-2018) [21] except for Cd and $\mathrm{Pb}$. The average concentrations of $\mathrm{Cd}$ and $\mathrm{Pb}$ are 8.5 times and 1.8 times of the screening values, indicating that part of the farmland in the study area has the risk of $\mathrm{Cd}$ and As pollution.

The antimony content obtained in this study is much higher than that reported in previous studies. In 2002, $\mathrm{He}$ and coworkers collected representative antimony contaminated soil and found that the Sb content ranged

Table 1. Evaluation standard classification of geological accumulation index.

\begin{tabular}{|c|c|c|}
\hline Pollution rank & $\mathrm{I}_{\text {geo }}$ & Pollution degree \\
\hline 0 & $\mathrm{I}_{\mathrm{geo}} \leq 0$ & Non pollution \\
\hline 1 & $0<\mathrm{I}_{\mathrm{geo}} \leq 1$ & Light pollution \\
\hline 2 & $1<\mathrm{I}_{\mathrm{geo}} \leq 2$ & Moderate pollution \\
\hline 3 & $2<\mathrm{I}_{\mathrm{geo}} \leq 3$ & Moderate pollution to strong pollution \\
\hline 4 & $3<\mathrm{I}_{\mathrm{geo}} \leq 4$ & Strong pollution \\
\hline 5 & $4<\mathrm{I}_{\mathrm{geo}} \leq 5$ & Strong pollution to extreme pollution \\
\hline 6 & $\mathrm{I}_{\mathrm{geo}}>5$ & Extreme pollution \\
\hline
\end{tabular}


Table 2. Statistical characteristics of heavy metal content in soil samples.

\begin{tabular}{|c|c|c|c|c|c|c|c|}
\hline Element & $\begin{array}{c}\text { Min } \\
(\mathrm{mg} / \mathrm{kg})\end{array}$ & $\begin{array}{c}\text { Max } \\
(\mathrm{mg} / \mathrm{kg})\end{array}$ & $\begin{array}{c}\text { Mean } \\
(\mathrm{mg} / \mathrm{kg})\end{array}$ & $\begin{array}{c}\text { Standard deviation } \\
(\mathrm{mg} / \mathrm{kg})\end{array}$ & $\begin{array}{c}\text { Coefficient } \\
\text { of Variation }\end{array}$ & $\begin{array}{c}\text { Background values } \\
(\mathrm{mg} / \mathrm{kg})\end{array}$ & $\begin{array}{c}\text { Filter values } \\
(\mathrm{mg} / \mathrm{kg})\end{array}$ \\
\hline $\mathrm{Ni}$ & 15.88 & 95.70 & 32.31 & 11.29 & 0.35 & 32.00 & 100 \\
\hline $\mathrm{Cu}$ & 13.90 & 129.00 & 32.52 & 15.29 & 0.47 & 26.00 & 100 \\
\hline $\mathrm{Pb}$ & 8.20 & 193.25 & 46.16 & 30.21 & 0.65 & 27.00 & 120 \\
\hline $\mathrm{Zn}$ & 50.00 & 2275.62 & 167.33 & 235.83 & 1.41 & 94.00 & 250 \\
\hline $\mathrm{Cr}$ & 45.00 & 156.00 & 86.23 & 21.76 & 0.25 & 68.00 & 200 \\
\hline $\mathrm{Cd}$ & 0.15 & 42.89 & 2.56 & 4.83 & 1.88 & 0.085 & 0.3 \\
\hline $\mathrm{As}$ & 9.57 & 552.00 & 52.73 & 61.55 & 1.17 & 14.00 & 30 \\
\hline $\mathrm{Sb}$ & 3.74 & 4320.00 & 413.21 & 698.33 & 1.69 & 2.98 & - \\
\hline $\mathrm{Hg}$ & 0.08 & 8.07 & 0.88 & 1.28 & 1.46 & 0.096 & 2.4 \\
\hline
\end{tabular}

from $100.6 \mathrm{mg} / \mathrm{kg}$ to $5045 \mathrm{mg} / \mathrm{kg}$ [22]; In 2012, $\mathrm{Ku}$ and coworkers reported the Sb content in the antimony mining areas ranged from $83.6 \mathrm{mg} / \mathrm{kg}$ to $2247.5 \mathrm{mg} / \mathrm{kg}$ [23]; In 2020, Huang and coworkers revealed that the average $\mathrm{Sb}$ content in this area reached $3619.38 \mathrm{mg} / \mathrm{kg}$ [24]. These studies show that with the progress of mining, the pollution of farmland soil is getting more and more pollution. Crommentuijn and coworkers reported that the maximum allowable antimony content in soil is $3.50 \mathrm{mg} / \mathrm{kg}$ [25], and the Sb content of all farmland soil samples has exceeded this value by up to 1234.3 times.

The coefficient of variation can be used to assess the interference of human factors on the accumulation of soil heavy metals. Generally, distributions with $\mathrm{CV}>1.0$ are considered as strong variance, distributions with $\mathrm{CV}$ between 0.1 and 1.0 are regarded as medium variance, and distributions with $\mathrm{CV}<0.1$ are recognized as weak variance [26]. The coefficient of variation of the soil heavy metals show the following order: $\mathrm{Cd}>\mathrm{Sb}>\mathrm{Hg}>\mathrm{Zn}>\mathrm{As}>\mathrm{Pb}>\mathrm{Cu}>\mathrm{Ni}>\mathrm{Cr}$. The coefficients of variation of $\mathrm{Cd}, \mathrm{Sb}, \mathrm{Hg}, \mathrm{Zn}$, and $\mathrm{As}$ are all greater than 1 (strong variance) with significant spatial variance, indicating the elevated contents of $\mathrm{Cd}, \mathrm{Sb}, \mathrm{Hg}, \mathrm{Zn}$, and As are likely to be affected by human factors; the coefficients of variation of $\mathrm{Pb}, \mathrm{Cu}, \mathrm{Ni}$, and $\mathrm{Cr}$ all lie between 0.1 and 1 , corresponding to medium variance.

\section{Spatial Distribution of Heavy Metals in Farmland Soil}

The concentration distributions of $\mathrm{Ni}, \mathrm{Cu}, \mathrm{Pb}, \mathrm{Zn}$, $\mathrm{Cr}, \mathrm{Cd}, \mathrm{As}, \mathrm{Sb}$, and $\mathrm{Hg}$ in the farmland soil in the mining area were plotted by using ArcGIS based on the coordinates of the sampling points and the content data of each element, as shown in Fig. 2.

The spatial distributions of $\mathrm{Cu}, \mathrm{Pb}, \mathrm{Zn}, \mathrm{Cr}$, and $\mathrm{Cd}$ show excessively high concentrations in the southwest, which may be related to point pollution. After investigation, it was found that the tailing ponds of the mining area are located in that area, indicating that $\mathrm{Cu}, \mathrm{Pb}, \mathrm{Zn}$, and $\mathrm{Cd}$ in farmland soil may come from the tailing ponds; $\mathrm{Ni}$ and $\mathrm{Cr}$ show band-shaped distributions, and the high $\mathrm{Ni}$ content area is mainly located in the northeastern part of the antimony mine, which is far away from the mining area, suggesting the Ni pollution is controlled by background sedimentation; The spatial distribution of $\mathrm{As}, \mathrm{Sb}$, and $\mathrm{Hg}$ are similar, and the high pollution areas are mainly located inside the mining area with non-point source distribution, indicating the contents of $\mathrm{As}, \mathrm{Sb}$, and $\mathrm{Hg}$ are influenced by mining activities. Mining activities generate a large amount of solid waste, such as waste rock and tailings. These solid wastes are piled in open places for a long time and pollute farmland soil through rainfall leaching [27]; Besides, heavy metal air pollutants, i.e. As, Sb and $\mathrm{Hg}$, emitted by the smelters in this area is the cause of regional surface pollution through dry and wet precipitation [28].

\section{The Impact of Land-Use Types on Heavy Metal Contents}

Based on the land-use type, the sampling sites can be divided into garden land and arable land. Fig. 3 shows the statistics of heavy metal content in the surface soil with different land-use types. As can be seen in the figure, the content ranges of $\mathrm{Cu}, \mathrm{Pb}, \mathrm{Zn}$, $\mathrm{Cr}, \mathrm{Ni}, \mathrm{Cd}, \mathrm{As}, \mathrm{Sb}$, and $\mathrm{Hg}$ in garden land are $13.9 \sim 70.4 \mathrm{mg} / \mathrm{kg}, 24.6 \sim 185 \mathrm{mg} / \mathrm{kg}, 66.5 \sim 930 \mathrm{mg} / \mathrm{kg}$, $52.6 \sim 156 \mathrm{mg} / \mathrm{kg}, 16.5 \sim 95.7 \mathrm{mg} / \mathrm{kg}, 0.15 \sim 16.8 \mathrm{mg} / \mathrm{kg}$, $10.4 \sim 137 \mathrm{mg} / \mathrm{kg}, \quad 3.74 \sim 4320 \mathrm{mg} / \mathrm{kg}$, and $0.09 \sim 8.07$ $\mathrm{mg} / \mathrm{kg}$, respectively; Their average contents are in the following order: $\mathrm{Sb}>\mathrm{Zn}>\mathrm{Cr}>\mathrm{Pb}>\mathrm{As}$ $>\mathrm{Ni}>\mathrm{Cu}>\mathrm{Cd}>\mathrm{Hg}$. The content ranges of $\mathrm{Cu}, \mathrm{Pb}$, $\mathrm{Zn}, \mathrm{Cr}, \mathrm{Ni}, \mathrm{Cd}, \mathrm{As}, \mathrm{Sb}$, and $\mathrm{Hg}$ in arable soil are $\quad 16.50 \sim 129 \mathrm{mg} / \mathrm{kg}, \quad 15.60 \sim 148.00 \quad \mathrm{mg} / \mathrm{kg}$, $50 \sim 1060.00 \mathrm{mg} / \mathrm{kg}, 50.6 \sim 152 \mathrm{mg} / \mathrm{kg}, 17.7 \sim 73 \mathrm{mg} / \mathrm{kg}$, $0.18 \sim 16 \mathrm{mg} / \mathrm{kg}, \quad 9.57 \sim 180 \mathrm{mg} / \mathrm{kg}, \quad 7.26 \sim 3240 \mathrm{mg} / \mathrm{kg}$ and $\quad 0.12 \sim 7.25 \mathrm{mg} / \mathrm{kg}$, respectively; Their average contents are in the following order: $\mathrm{Sb}>\mathrm{Zn}>\mathrm{Cr}>\mathrm{Pb}>\mathrm{As}>\mathrm{Ni}>\mathrm{Cu}>\mathrm{Cd}>\mathrm{Hg}$. 
The average contents of heavy metal elements in garden land, especially $\mathrm{Sb}$ and $\mathrm{Zn}$, are higher than those of arable land, which indicates that different farming modes affect the accumulation of $\mathrm{Sb}$ and $\mathrm{Zn}$. The large difference in $\mathrm{Sb}$ content may be related to the higher usage of Sb-contaminated irrigation water in garden land than the arable land.

Fig. 4 shows the influence of different planting modes on the chemical state of As and $\mathrm{Sb}$. Compared with the As composition in garden land, the reducible arsenic in arable land was reduced by $3.30 \%$, while the residual As content was increased by $3.88 \%$. This may due to the geochemical behavior of As. The As(III) in arable land has more interaction with oxygen resulting in forming a higher percentage of $\mathrm{As}(\mathrm{V})$, and the poor migration rate of $\mathrm{As}(\mathrm{V})$ leads to the accumulation of $\mathrm{Ab}$ in the residual state. The planting mode has little effect on the chemical state of $\mathrm{Sb}$, which may be related to the higher migration rate of $\mathrm{Sb}(\mathrm{V})$ than that of $\mathrm{Sb}$ (III).
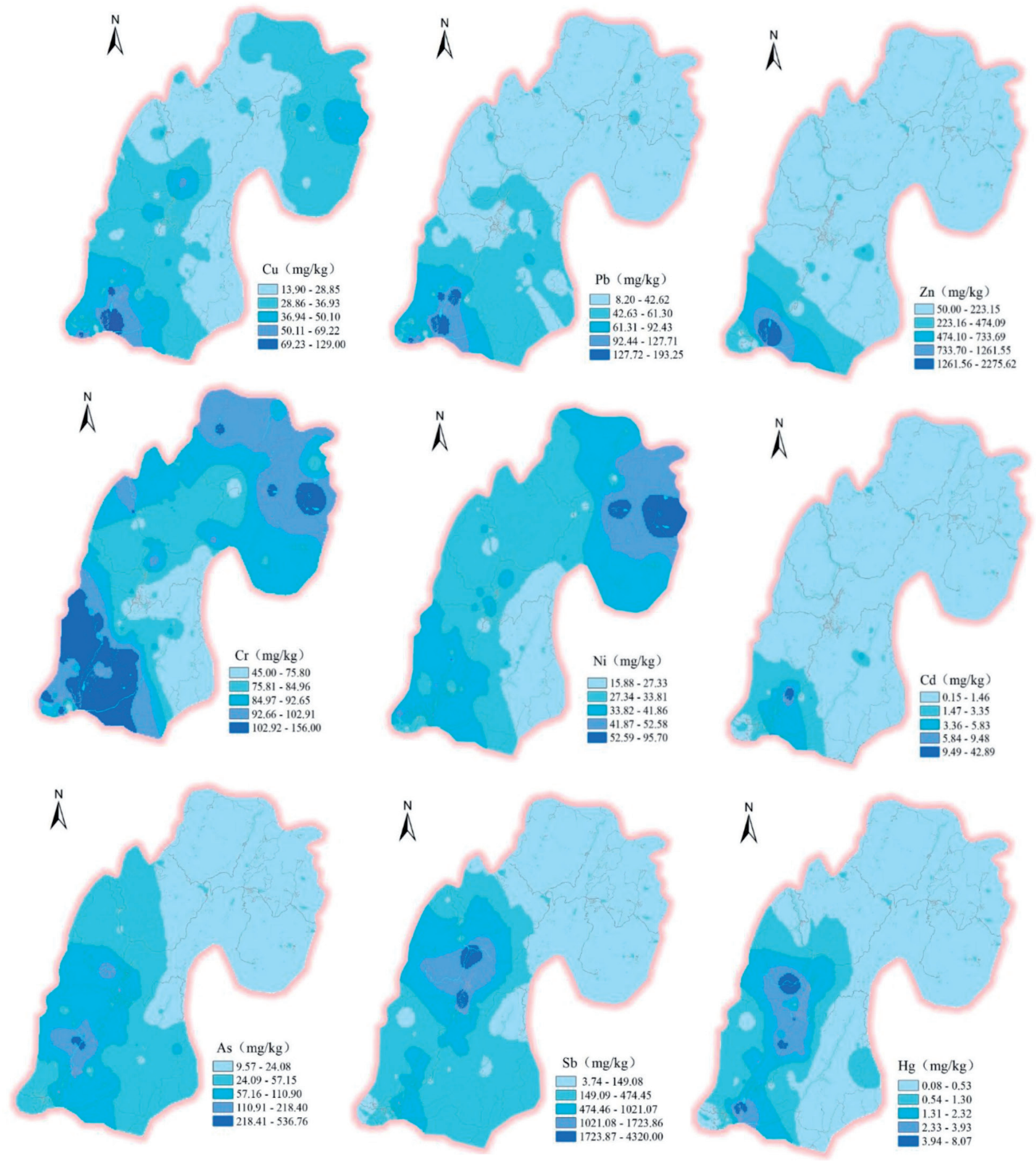

Fig. 2. Results of spatial distribution. 

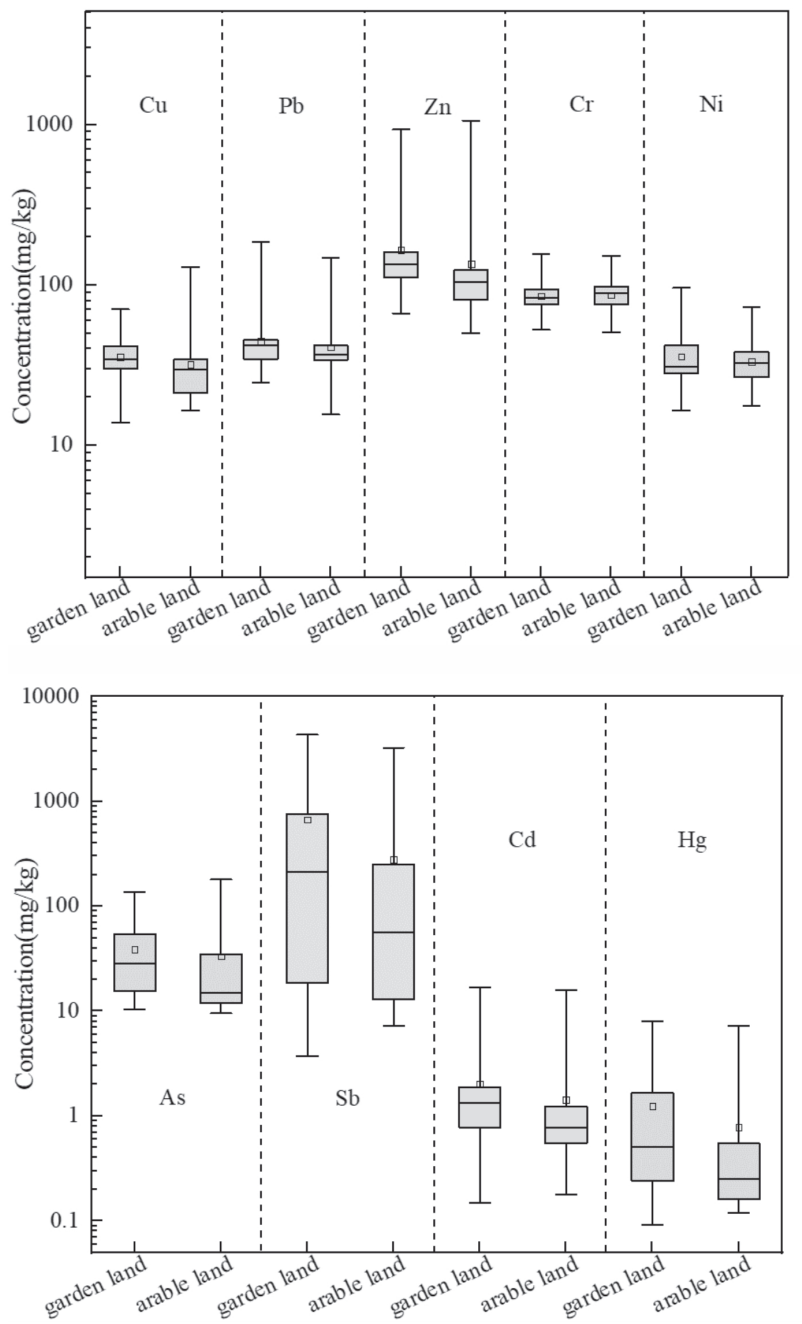

Fig. 3. Characteristics of heavy metal content under different land-use types.

\section{Pollution Evaluation with Geoaccumulation Index}

\section{Determination of Geochemical Baseline Values}

In this study, Ti is selected as the standard element. The linear regression equations between $\mathrm{Ti}$ and other heavy metal elements ( $\mathrm{As}, \mathrm{Sb}, \mathrm{Cu}, \mathrm{Ni}, \mathrm{Cd}, \mathrm{Hg}, \mathrm{Cr}, \mathrm{Pb}$, and $\mathrm{Zn}$ ) were first established based on Eq. (1). Then, the geochemical baseline value of each heavy metal element (Table 3) was obtained using Eq. (2).

Compared with the soil background values of Hunan Province, the obtained baseline values of $\mathrm{Ni}, \mathrm{Cu}, \mathrm{Pb}, \mathrm{Zn}$, $\mathrm{Cr}, \mathrm{Cd}, \mathrm{As}, \mathrm{Sb}$, and $\mathrm{Hg}$ are generally higher, especially for $\mathrm{As}$ and $\mathrm{Sb}$. The increase in the baseline values of these elements indicates the influence of human factors such as mining and smelting on the accumulation of heavy metals in the soil. Therefore, utilizing the baseline value as an evaluation method can objectively reflect the accumulation of heavy metal pollutants in the soil.
Table 3. Geochemical baseline values.

\begin{tabular}{|c|c|c|c|}
\hline Element & Baseline equation & $\mathrm{R}$ & $\begin{array}{c}\text { Baseline } \\
\text { value }\end{array}$ \\
\hline $\mathrm{Ni}$ & $B_{m}=0.008 C_{N}-7.479$ & 0.528 & 34.44 \\
\hline $\mathrm{Cu}$ & $B_{m}=0.005 C_{N}+2.871$ & 0.318 & 29.07 \\
\hline $\mathrm{Pb}$ & $B_{m}=0.006 C_{N}+4.391$ & 0.259 & 35.83 \\
\hline $\mathrm{Zn}$ & $B_{m}=0.022 C_{N}+18.44$ & 0.144 & 133.72 \\
\hline $\mathrm{Cr}$ & $B_{m}=0.013 C_{N}+9.428$ & 0.564 & 77.55 \\
\hline $\mathrm{Cd}$ & $B_{m}=0.000 C_{N}+0.963$ & 0.036 & 0.96 \\
\hline $\mathrm{As}$ & $B_{m}=-0.009 C_{N}+90.29$ & 0.182 & 43.13 \\
\hline $\mathrm{Sb}$ & $B_{m}=-0.151 C_{N}+1332.6$ & 0.154 & 541.36 \\
\hline $\mathrm{Hg}$ & $B_{m}=0.000 C_{N}+1.799$ & 0.095 & 1.80 \\
\hline
\end{tabular}

\section{Pollution Evaluation Results}

The geological accumulation index (Igeo) of each heavy metal in the soil samples and the corresponding pollution levels were calculated using Eq. (3) and the geochemical baseline values (Table 3). The results are shown in Fig. 5. It can be seen that the farmland soil has been polluted by heavy metals to varying degrees, and the overall pollution level is light. In some areas, the Cd pollution level has reached moderate to strong pollution, and the $\mathrm{Sb}$ and $\mathrm{Zn}$ pollution levels have reached moderate to moderate to severe pollution.

According to the average Igeo, the pollution levels of these heavy metals show the following trend: $\mathrm{Cr}>\mathrm{Cu}>\mathrm{Pb}>\mathrm{Cd}>\mathrm{Ni}>\mathrm{Zn}>\mathrm{As}>\mathrm{Sb}>\mathrm{Hg}$. The Igeo value of $\mathrm{Cd}$ varies from -3.26 to 3.54 , which covers all five pollution levels. Among them, the percentage of the samples with non $\mathrm{Cd}$ pollution, light $\mathrm{Cd}$ pollution, moderate $\mathrm{Cd}$ pollution, moderate to strong $\mathrm{Cd}$ pollution, and strong $\mathrm{Cd}$ pollution are $72.45 \%, 19.39 \%, 4.08 \%$, $2.04 \%$, and $2.04 \%$, respectively; The max geological accumulation index of $\mathrm{Sb}$ and $\mathrm{Zn}$ are more than 2, and they are in a moderate to strong pollution state, indicating that the pollution risk of heavy metal elements in $\mathrm{Sb}$ and $\mathrm{Zn}$ is high. The geological accumulation index of As varies from -2.76 1.48, in which As is non pollution, light pollution and moderate pollution state, and the proportions of sample points account for $77.55 \%, 14.29 \%$, and $8.16 \%$ of the total number of samples respectively. The pollution levels of $\mathrm{Ni}, \mathrm{Cu}, \mathrm{Pb}$, $\mathrm{Cr}$, and $\mathrm{Hg}$ are all at the light pollution.

Based on the geological accumulation pollution index, the pollution distribution maps of the nine heavy metal elements were plotted, as shown in Fig. 6. Ni and $\mathrm{Cr}$ are generally at the non pollution level and their Igeo values are affected by the soil background value. The farmland in the southwest of Kuangshan township, close to the Longwangchi tailing dam, is strongly polluted by $\mathrm{Zn}$ and $\mathrm{Cd}$. As the river water in this area is polluted by the infiltration and seepage of tailings, irrigation 


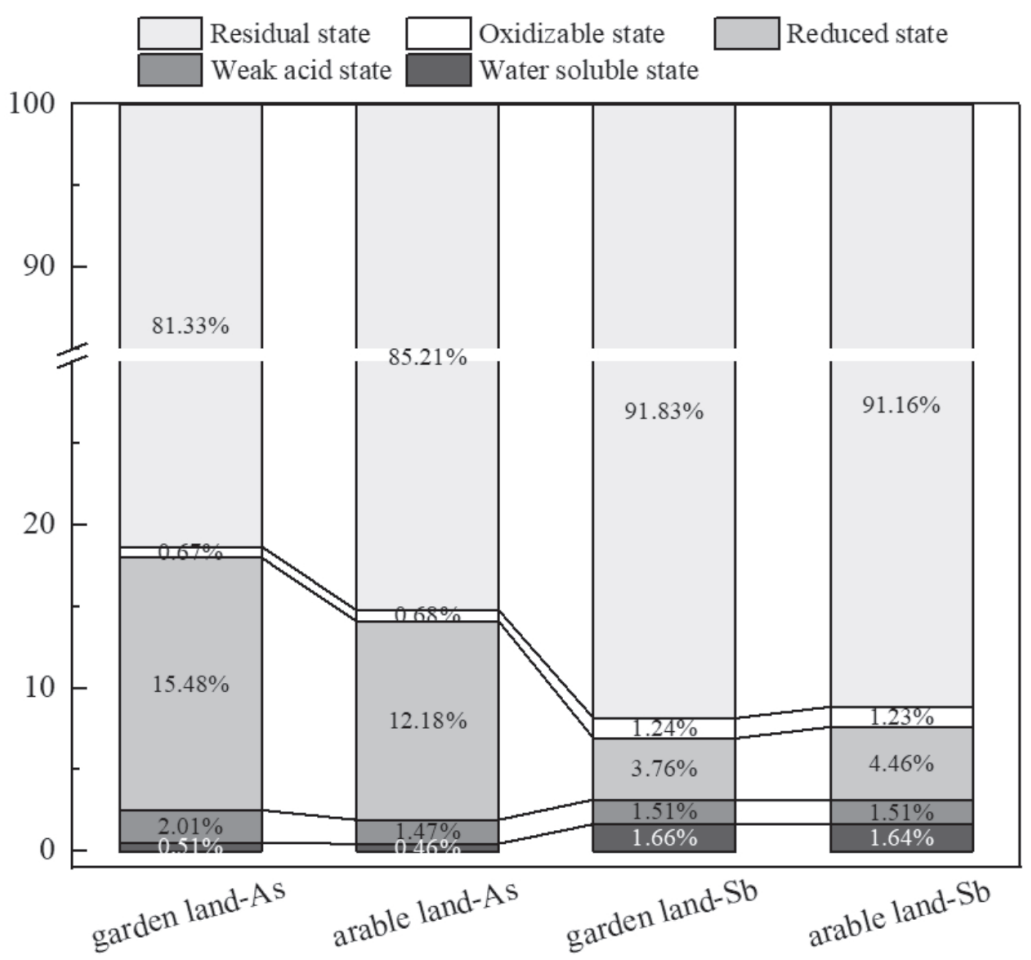

Fig. 4. The morphological composition diagram of the elements As and $\mathrm{Sb}$ under different planting modes

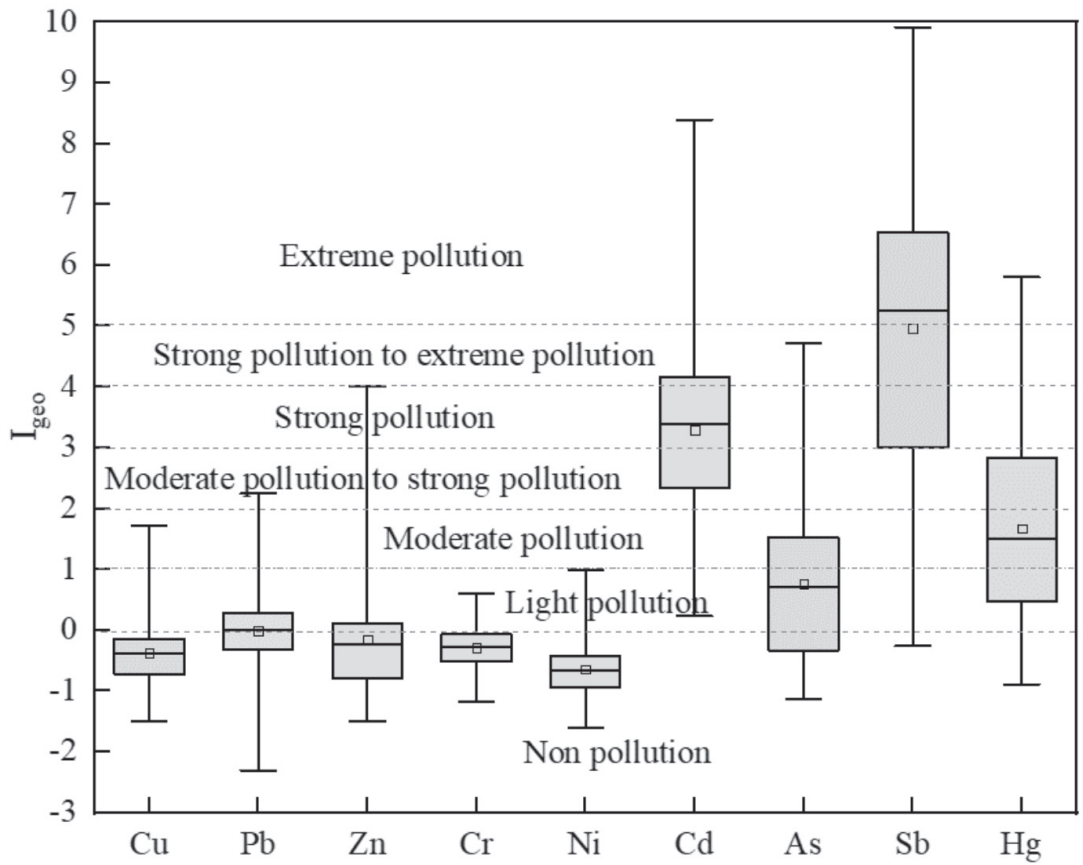

Fig. 5. Box diagram of Geological accumulation index evaluation.

with the polluted river water results in a high degree of enrichment of $\mathrm{Zn}$ and $\mathrm{Cd}$. The high $\mathrm{Sb}$ polluted area is mainly located near the Nankuang smelter area, where the heavy metal polluted wastewater discharge ports of two mining and smelting companies (Jinbo Antimony Development Co. Ltd and Shizishan Antimony Co. Ltd) are located. And the $\mathrm{Sb}$ in the wastewater enters the surface soil through rainwater infiltration. Besides, the high $\mathrm{Hg}$ polluted area also appears in the same area, which is caused by the dry and wet sedimentation of the Hg-containing waste gas generated from the smelting process. 

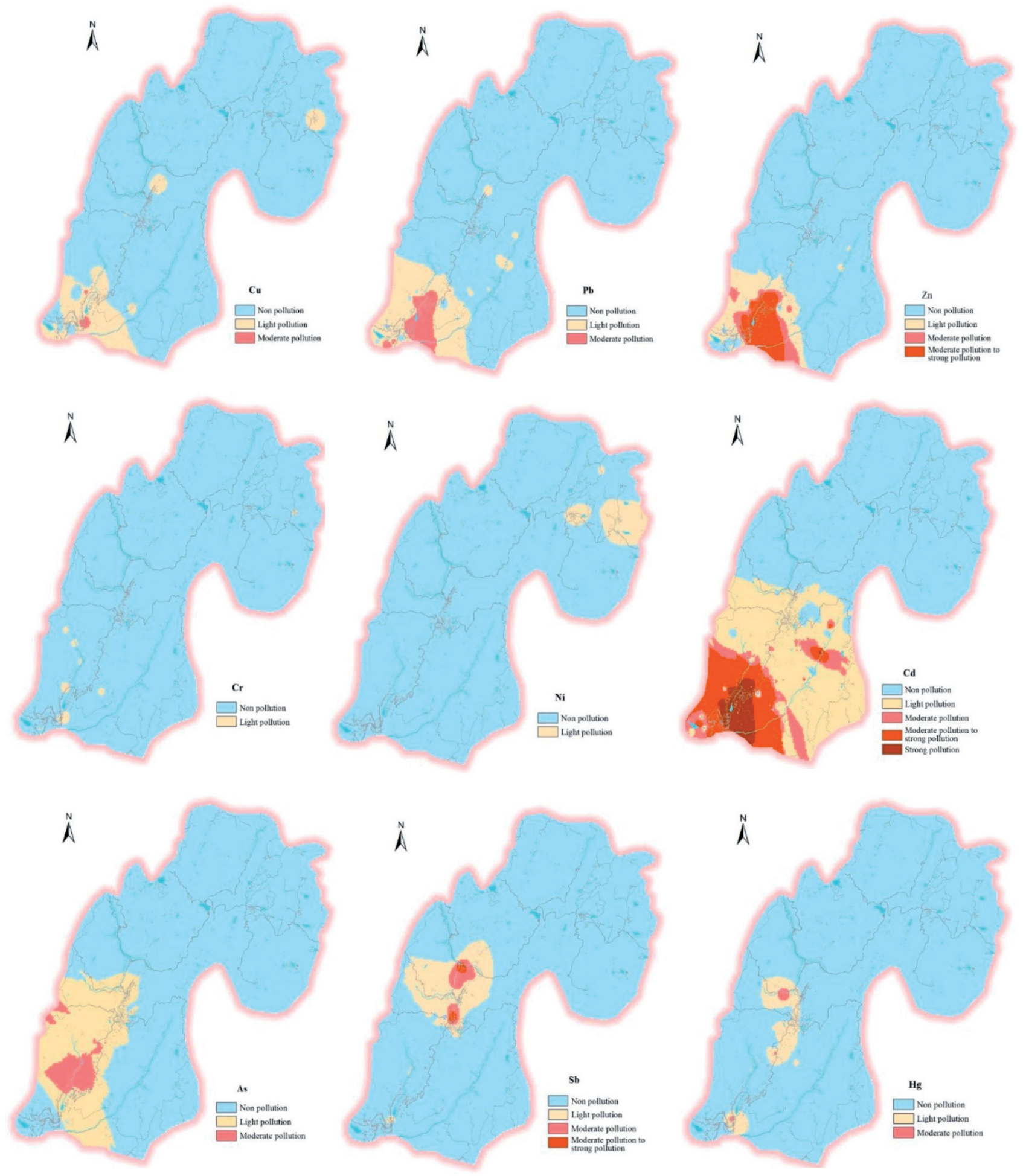

Fig. 6. Results of Pollution distribution.

\section{Source Analysis of Soil heavy Metals}

\section{Correlation Analysis}

Table 4 shows the Pearson correlation coefficients of the 9 heavy metal elements in the agricultural topsoil of Kuangshan township. If the correlation of two elements is significant, the two elements have similar geochemical behaviors such as source or migration [29].
Wang found that that the $\mathrm{pH}$ value of the soil affects the adsorption-desorption of heavy metal ions [30]. As shown in Table 4, the correlation coefficients between soil $\mathrm{pH}$ value and various metal elements are small, indicating the correlation between soil $\mathrm{pH}$ and each heavy metal element is not significant. Hence, soil pH is not the main factor influencing heavy metal pollution. In addition, the correction coefficients between $\mathrm{Cu}$ and $\mathrm{Pb}$ $(r=0.780), \mathrm{Cu}$ and $\mathrm{Cr}(r=0.647), \mathrm{Pb}$ and $\mathrm{Zn}(r=0.783)$, 
Table 4. Correlation analysis of heavy metal elements.

\begin{tabular}{|c|c|c|c|c|c|c|c|c|c|c|}
\hline & $\mathrm{Cu}$ & $\mathrm{Pb}$ & $\mathrm{Zn}$ & $\mathrm{Cr}$ & $\mathrm{Ni}$ & $\mathrm{Cd}$ & $\mathrm{As}$ & $\mathrm{Sb}$ & $\mathrm{Hg}$ & $\mathrm{pH}$ \\
\hline $\mathrm{Cu}$ & 1.000 & & & & & & & & & \\
\hline $\mathrm{Pb}$ & $0.780^{* *}$ & 1.000 & & & & & & & & \\
\hline $\mathrm{Zn}$ & $0.602^{* *}$ & $0.783^{* *}$ & 1.000 & & & & & & & \\
\hline $\mathrm{Cr}$ & $0.647^{* *}$ & $0.448^{* *}$ & $0.335^{* *}$ & 1.000 & & & & & & \\
\hline $\mathrm{Ni}$ & $0.481^{* *}$ & 0.138 & 0.156 & $0.746^{* *}$ & 1.000 & & & & & \\
\hline $\mathrm{Cd}$ & $0.546^{* *}$ & $0.806^{* *}$ & $0.953^{* *}$ & $0.300^{* *}$ & 0.074 & 1.000 & & & & \\
\hline $\mathrm{As}$ & $0.194^{*}$ & $0.188^{*}$ & $0.296^{* *}$ & 0.130 & 0.125 & $0.299^{* *}$ & 1.000 & & & \\
\hline $\mathrm{Sb}$ & 0.140 & 0.029 & 0.080 & -0.102 & -0.006 & 0.056 & $0.341^{* *}$ & 1.000 & & \\
\hline $\mathrm{Hg}$ & $0.280^{* *}$ & $0.319^{* *}$ & $0.325^{* *}$ & -0.017 & 0.002 & $0.299^{* *}$ & $0.485^{* *}$ & $0.496^{* *}$ & 1.000 & \\
\hline $\mathrm{pH}$ & -0.059 & -0.085 & 0.090 & 0.025 & -0.054 & 0.049 & 0.173 & 0.098 & -0.004 & 1.000 \\
\hline
\end{tabular}

** the correlation was significant at $\mathrm{P}<0.01$ level (bilateral);

* the correlation was significant at $\mathrm{P}<0.05$ level (bilateral).

$\mathrm{Pb}$ and $\mathrm{Cd}(r=0.806), \mathrm{Zn}$ and $\mathrm{Cd}(r=0.953)$, as well as $\mathrm{Ni}$ and $\mathrm{Cr}(r=0.746)$ are all greater than 0.5 (significant positive correlation, $P<0.01$ ), indicating that $\mathrm{Cu}, \mathrm{Pb}, \mathrm{Cr}$, and $\mathrm{Ni}$ may have similar pollution sources, and $\mathrm{Zn}$ and $\mathrm{Cd}$ may have similar geochemical behaviors. Besides, $\mathrm{Hg}$ has significant positive correlations with As $(r=0.485)$ and $\mathrm{Sb}(r=0.496)$, suggesting they may have similar pollution sources. According to the correlation coefficient analysis, the sources of the heavy metal elements in the study area are complex, which requires further analysis.

\section{PMF Source Analysis}

The EPA PMF5.0 model was applied to analyze the sources of the nine heavy metal pollutants. The pollution sources and contribution ratios of the nine heavy metals are shown in Fig. 7.

Factor 1 is dominated by As (69.7\%), Sb (96.1\%), and $\mathrm{Hg}(58.6 \%)$, and this factor is mainly associated with the mining and smelting activities of antimony. Frequent mining activities and long-term piling of waste rocks and slag results in the pollution of $\mathrm{Sb}$ and other
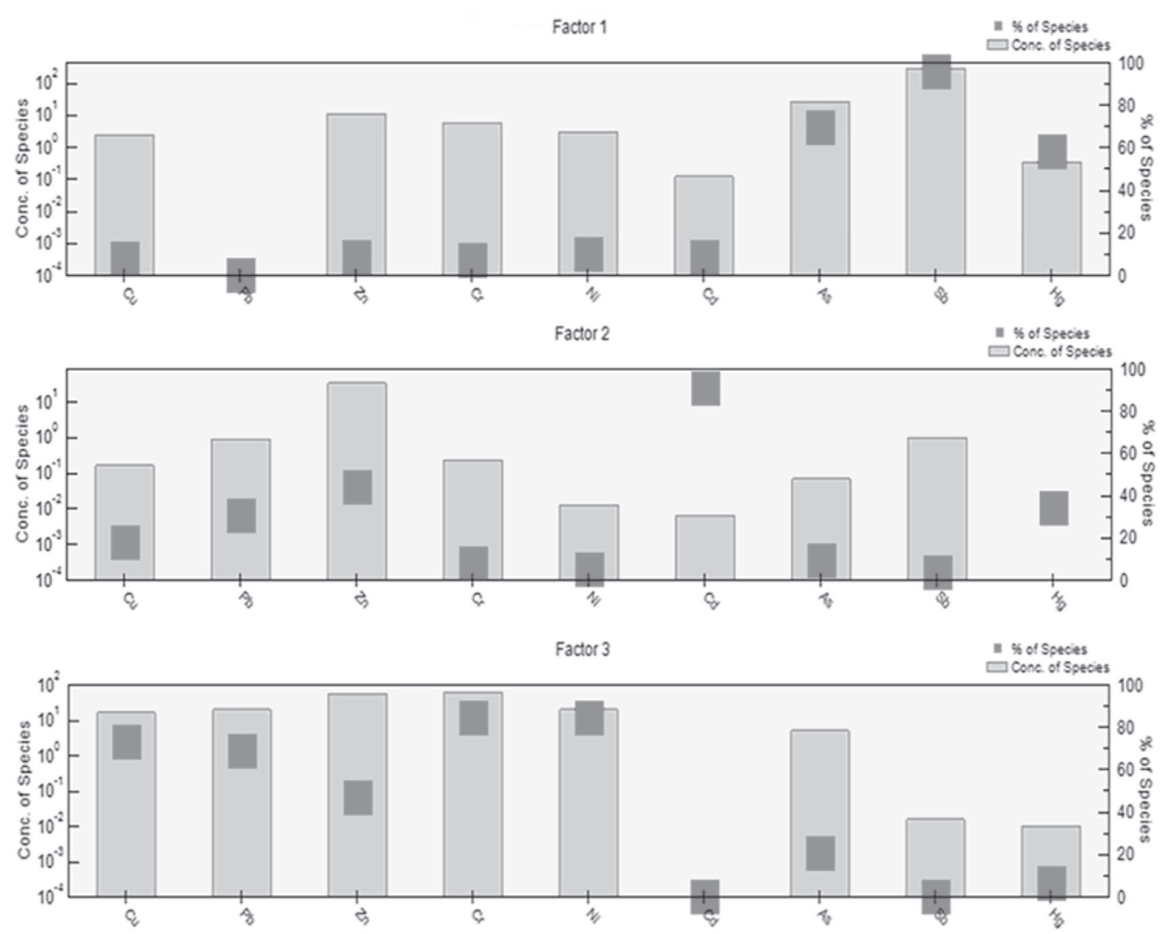

Fig. 7. Contributions of three main factors to nine heavy metals. 


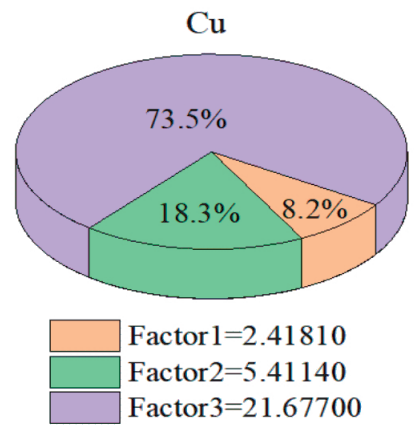

$\mathrm{Cd}$

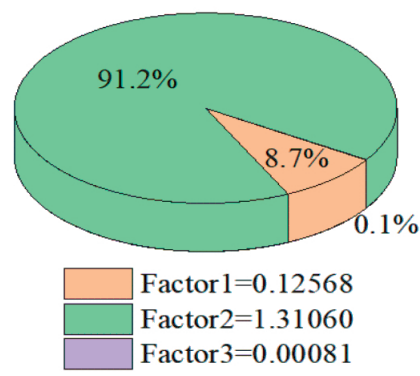

As

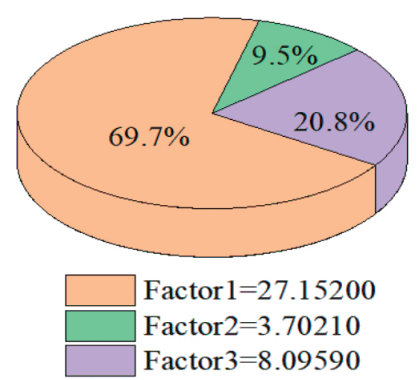

$\mathrm{Pb}$

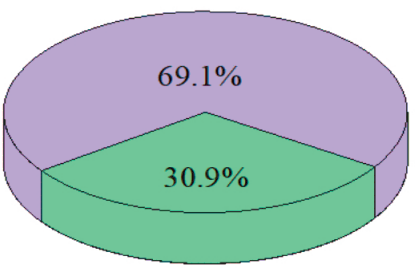

Factor $2=11.55500$

Factor $3=25.82500$

$\mathrm{Ni}$

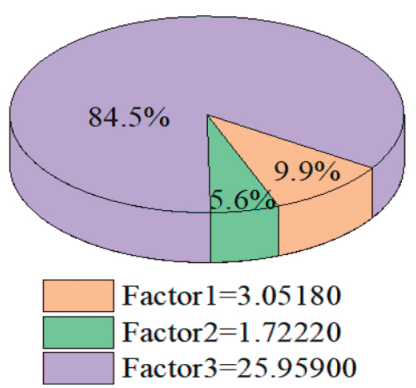

$\mathrm{Sb}$

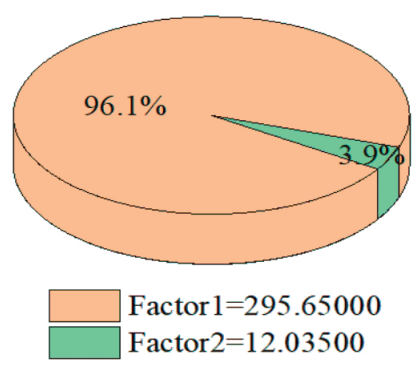

$\mathrm{Zn}$

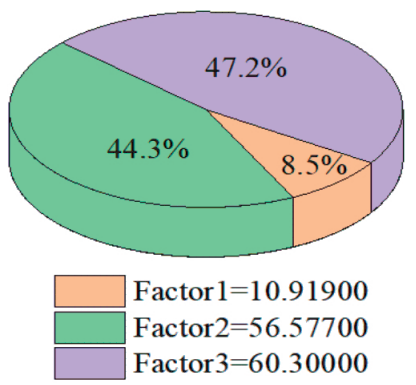

$\mathrm{Cr}$

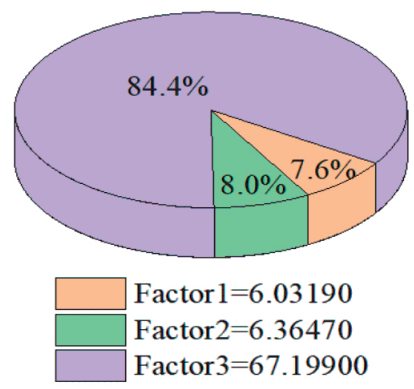

$\mathrm{Hg}$

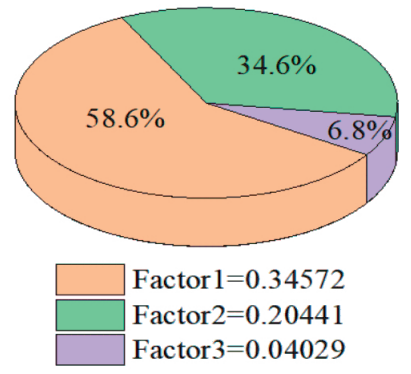

Fig. 8. The factor contribution rate of each heavy metal.

associated heavy metal elements (i.e. As and $\mathrm{Hg}$ ) in the farmland soil in the mining area. In addition, arsenicalkali slag (mainly $\mathrm{Na}_{2} \mathrm{AsO}_{4}$ ) is a characteristic pollutant produced from the mining and smelting process in this area [31]. During the antimony smelting process, the crude antimony is refined by adding sodium carbonate to remove arsenic. The by-product of this process, $\mathrm{Na}_{2} \mathrm{AsO}_{4}$ [32], is toxic and highly water-soluble, and it can enter the farmland soil through surface runoff, resulting in the As pollution of farmland soil. Therefore, factor 1 is assumed to be a mining activity source.

Factor 2 is represented by $\mathrm{Cd}(91.2 \%)$. The main pollution source of $\mathrm{Cd}$ in farmland soil is agricultural activities, including the usage of organic fertilizers, chemical fertilizers, and pesticides [33]. Therefore, factor 2 represents an agricultural activity source.

Factor 3 is characterized by the presence of $\mathrm{Cu}$ (73.5\%), Pb (69.1\%), Cr (84.4\%), Ni (84.5\%), and $\mathrm{Zn}$ (47.2\%). Generally, heavy metals related to soil parent materials are the elements with low pollution levels [34]. Researches on the sources of $\mathrm{Cu}, \mathrm{Cr}$, and $\mathrm{Ni}$ shows that $\mathrm{Cu}, \mathrm{Cr}$, and $\mathrm{Ni}$ mainly come from soil parent materials
[35]. The sources of $\mathrm{Pb}$ and $\mathrm{Zn}$ are more complicated, and their contributions are lower than that of $\mathrm{Cu}, \mathrm{Cr}$, and $\mathrm{Ni}$ and can be ignored. Therefore, factor 3 can be identified as a natural source.

Fig. 8 shows the pie charts of the pollution sources of the nine heavy metal elements: The contributions of the mining activity source, the agricultural activity source, and the natural source to the As pollution are $69.70 \%, 9.50 \%$, and $20.80 \%$, respectively; The contributions of the mining activity source, the agricultural activity source, and the natural source to the $\mathrm{Sb}$ pollution are $96.10 \%$ and $3.90 \%$, respectively; The contributions of the mining activity source, the agricultural activity source, and the natural source to the $\mathrm{Hg}$ pollution are $58.60 \%, 34.60 \%$, and $6.80 \%$, respectively; The contributions of the mining activity source, the agricultural activity source, and the natural source to the $\mathrm{Cd}$ pollution are $8.70 \%, 91.20 \%$, and $0.10 \%$, respectively; The contributions of the mining activity source, the agricultural activity source, and the natural source to the $\mathrm{Cu}$ pollution are $8.20 \%$, $18.30 \%$, and $73.50 \%$, respectively; The contributions of the agricultural activity source and the natural source 
to the Pd pollution are $30.90 \%$ and $69.10 \%$, respectively; The contributions of the mining activity source, the agricultural activity source, and the natural source to the $\mathrm{Zn}$ pollution are $8.50 \%, 44.30 \%$, and $47.20 \%$, respectively; The contributions of the mining activity source, the agricultural activity source, and the natural source to the $\mathrm{Cr}$ pollution are $7.60 \%, 8.00 \%$, and $84.40 \%$, respectively; The contributions of the mining activity source, the agricultural activity source, and the natural source to the Ni pollution are $9.90 \%, 5.60 \%$, and $84.50 \%$, respectively.

\section{Conclusion}

(1) The average contents of $\mathrm{Ni}, \mathrm{Cu}, \mathrm{Pb}, \mathrm{Zn}, \mathrm{Cr}, \mathrm{Cd}$, $\mathrm{As}, \mathrm{Sb}$, and $\mathrm{Hg}$ in the farmland soil of antimony mine are higher than the background values of the surface soil in Hunan province. And the mean concentrations of $\mathrm{Cd}$ and As have exceeded China's soil pollution risk screening values for agricultural land. The highest $\mathrm{Sb}$ content obtained in this study is 1234.3 times of the maximum allowable antimony content. The average content of heavy metal elements in the farmland soil shows the following order: $\mathrm{Sb}>\mathrm{Zn}>\mathrm{Cr}>\mathrm{As}>\mathrm{Pb}>\mathrm{Ni}>\mathrm{Cu}>$ $\mathrm{Cd}>\mathrm{Hg}$. The content of each heavy metal in garden land is higher than that in arable land.

(2) Geoaccumulation index analysis results suggest the overall pollution level of the farmland soil in the study area is slightly polluted. In some areas, the pollution level of $\mathrm{Cd}$ has reached moderate to strong pollution; the pollution levels of $\mathrm{Sb}$ and $\mathrm{Zn}$ appear to be moderate pollution to moderate to severe pollution; the pollution levels of $\mathrm{Ni}, \mathrm{Cu}, \mathrm{Pb}, \mathrm{Cr}, \mathrm{As}$, and $\mathrm{Hg}$ are at moderate pollution to light pollution.

(3) The correlation analysis and PMF analysis reveal that $\mathrm{As}, \mathrm{Sb}$, and $\mathrm{Hg}$ are mainly caused by the mining activity, the agricultural activity is the main reason for the accumulation of $\mathrm{Cd}$, and natural factors are the main sources of $\mathrm{Cu}, \mathrm{Pb}, \mathrm{Cr}, \mathrm{Ni}$, and $\mathrm{Zn}$ in the study area.

\section{Acknowledgments}

This work were funded by the Ecological Environment Carrying Capacity Evaluation Project of Lengshuijiang Tin Mine of Hunan Province (No. LCG2020009) and Postgraduate Innovation Funding Project of Hebei Province (No.CXZZSS2021166).

\section{Conflict of Interest}

There is no potential conflict of interest in what is stated herein.

\section{References}

1. ARAO T., ISHIKAWA S., MURAKAMI M., ABE K., MAEJIMA Y., MAKINO T. Heavy metal contamination of agricultural soil and countermeasures in Japan [J]. Paddy \& Water Environment. 8 (3), 247, 2010.

2. WANG J., CHEN C. Biosorption of heavy metals by Saccharomyces cerevisiae: a review $[\mathrm{J}]$. Biotechnology Advances. 24 (5), 427, 2006.

3. FU S. Heavy Metal Distribution and Ecological risk Assessment in Xikuangshan Hunan Province[D]. Nanchang University, 2010.

4. CAI F., REN J.H., TAO S., WANG X.L. Uptake, translocation and transformation of antimony in rice (Oryza sativa L.) seedlings. Environmental Pollution. 209 (169-176), 2016.

5. JIANG Y.R., LIANG Y., ZHANG X.H., QIN Y.L., WU C.C., LI X.J. Vertical Microbial Community Structure of Heavy Metal Contaminated Soils from Mine Tailings of Different Degrees in Lead-zinc Mining Areas. Ecology and Environmental Sciences. 28 (10), 2079, 2019.

6. RODRÍGUEZ L., RUIZ E., ALONSO-AZCÁRATE J., RINCÓN J. Heavy metal distribution and chemical speciation in tailings and soils around a $\mathrm{Pb}-\mathrm{Zn}$ mine in Spain. 90 (2), 1106, 2009.

7. THELMA A., SANDRA B., SHERINGHAM B.L., MATT D., GODFRED D. Distribution of heavy metals in soils from abandoned dump sites in Kumasi, Ghana. Scientific African. 10, 2020.

8. WANG X.L., WANG X., LIU T.Y., GAO.Z., HUANG Z.Y., YU F.X. Contaminated Situation and Remediation Practice of the Main Types by Heavy Metals in Jiangxi Province [J]. Jiangxi Science. 32 (05), 594, 2014.

9. WEN H.J., ZHANG Y.X., CLOQUET C., ZHOU C.W. Tracing sources of pollution in soils from the Jinding $\mathrm{Pb}-\mathrm{Zn}$ mining district in China using cadmium and lead isotopes[J]. Applied Geochemistry. 52, 147, 2015.

10. MO C.L., WU F.C., FU Z.Y., ZHU J., RAN L. Antimony, Arsenic and Mercury Pollution in Agricultural Soil of Antimony Mine Area in Xikuangshan, Hunan. Acta Mineralogica Sinica. 33 (03), 344, 2013.

11. HE M.C., WANG H.Y. Distribution, Speciation, Toxicity and Bioavailability of Antimony in the Environment. Progress in Chemistry. 01, 131, 2004.

12. HE M.C. Distribution and phytoavailability of antimony at an antimony mining and smelting area, Hunan, China, Environ Geochem Health. 29 (3), $209,2007$.

13. WEI L.H., WANG D.J., BI J.P., XIE J. Dynamic Monitoring and Assessment of Ecologic Environment in Xikuangshan Antimony Mining Area Based on Remote Sensing. Environmental Science \& Technology. 06, 230, 2020.

14. TENG Y.G., NI S.J. Theory and Practice of Geochemical Baseline. Chemical Industry Press. 2007.

15. HAO C.M., CHEN Y.J., LI R.M., HE X.W. Evaluation of Heavy Metal Pollution in Farmland Soils in Pinghu City Based on Geochemical Standardization Methods. Environmental Pollution \& Control. 31 (02), 96, 2009.

16. ZHOU J.W., ZHOU J. Y., DAI L., ZHONG J.X., LIU Z.X., ZHU Z.Y. Establishment of Topsoil Geochemical Baseline Value in the Concentrated Mining Area of the Lala Copper Ore, China. Chinese Journal of Soil Science. 50 (02), 427, 2019. 
17. FAN S.X. Pollution and health risk assessment of heavy metals in soil neighborhoods around a smelter in Changqing town of Baoji city. Environmental Pollution \& Control. 37 (09), 46, 2015.

18. TANG Z.E., DENG R.J., ZHANG J., REN B.Z., HURSTHOUSE A. Regional distribution characteristics and ecological risk assessment of heavy metal pollution of different land use in an antimony mining area Xikuangshan, China. Human and Ecological Risk Assessment. 2020.

19. PAN Y.M., YANG G.Z. Soil Background Value and Research Methods in Hunan. Beijing: China Environmental Science Press. 1988.

20. WEI Q., JIN L.X., CHEN W. Y., GU H. Pollution Characteristics and Source Analysis of Heavy Metals in Sediment of Panlong River. Shandong Agricultural Sciences. 52 (07), 75, 2020.

21. Ministry of Ecology and Environment, PRC, \& State Administration for Market Regulation,Soil environmental quality Risk control standard for soil contamination of agricultural land (GB15618-2018), 2018.

22. HE M.C., JI H.B., ZHAO C.Y., XIE J., WU X.M., LI Z.F. Preliminary Study of Heavy Mental Pollution in Soil and Plant Near Antimony Mine Area. Journal of Beijing Normal University(Natural Science). 03, 417, 2002.

23. KU W.Z., ZHAO Y.L., LEI C.X., DONG M., DAI M.B., YI H.C. Heavy metal pollution in soils and characteristics of heavy metal accumulation of dominant plants in antimony mining area. Chinese Journal of Environmental Engineering. 6 (10), 3774, 2012.

24. HUANG Z.J., DENG R.J., ZHOU S.J., WANG J.Q. Effects of mining activities on soil heavy metal pollution characteristics and ecological risks in antimony mining areas. Journal of Civil and Environmental Engineering. 42 (04), 194, 2020.

25. CROMMENTUIJN T., SIJM D., BRUIJN J., HOOP M., LEEUWEN K., PLASSCHE E. Maximum permissible and negligible concentrations for metals and metalloids in the Netherlands, taking into account background concentrations. Journal of Environmental Management. 60 (2), 121, 2000.
26. DENG X., SUN H.L., YANG Y.H., ZHOU Y.C., WU S.S. Pollution assessment and source apportionment of heavy metals in Yining City soil. Environmental Pollution \& Control. 42 (02), 223, 2020.

27. WEI Z.Y. Environmental Health Effect of Antimony:a Review of Recent Researches. Journal of Environment and Health. 28 (07), 649, 2011.

28. FU Z.Y., WU F.C., MO C.L., LIU B.J., ZHU J., DENG Q.J., LIAO H.Q., ZHANG Y.S. Bioaccumulation of antimony, arsenic, and mercury in the vicinities of a large antimony mine, China. Microchemical Journal. 97 (1), 12, 2011.

29. DONG L.K., FANG B. Analysis of spatial heterogeneity of soil heavy metals in tea plantation:Case study of high quality tea garden in Jiangsu and Zhejiang. Geographical Research. 36 (02), 391, 2017.

30. WANG Y.X. Analysis and assessment of heavy metal goncentration of vegetable cultivated soils in Anning District of Lanzhou. Lanzhou: Gansu Agricultural University. 2007.

31. WEN B., ZHOU A.G., ZHOU J.W., LIU C.F., HUANG Y.L., LI L.G. Coupled $\mathrm{S}$ and $\mathrm{Sr}$ isotope evidences for elevated arsenic concentrations in groundwater from the world's largest antimony mine, Central China. 557, 211, 2018.

32. PENG X. Study on Second Arsenic-Alkali slag of Antimony Smelting in Hydrothermal Leaching. Hunan Nonferrous Metals. 29 (01), 54, 2013.

33. YIN F., FENG K., YIN C.J., BAI D.Z., WANG R., ZHOU Y.Y., LIANG Y.C., LIU L. Evaluation and source analysis of heavy metal in cultivated soil around typical industrial district of Huangshui watershed, Qinghai province. China Environmental Science. 1-12, 2021.

34. CHAI L., WANG X., MA L., CHENG Z.X., SU L.M., WANG Y.H. Sources appointment of heavy metals in cultivated soils of Lanzhou based on PMF models. China Environmental Science. 40 (09), 3919, 2020.

35. ZHOU X., LV J.S. Sources, distribution and ecological risks of soil heavy metals in Guangrao County, Shandong Province. Geographical Research. 38 (2), 224, 2019. 